by their irregularity, that all organic origin is excluded, sometimes in ice; they originate in the hardening together of crystals, under pressure, and are only the imprisoned, often stem-like and branded hollows of air. Like Eozöon they become afterwards filled with foreign matter, with serpentine and chrysotile, re sulting out of the watery decumposition of olivine.

To show how analogous circumstances are also applicable to the origin of Eozöon, I shall first refute the two erroneous arguments often adduced for the organic existence in the laurentian period : the presence of graphite and the stratification of the oldest rocks.

Graphite, as Dr. Moebius supposes, cannot be a sign of primitive organic life. (I) In the oldest period there certainly lived only the most primitive lower beings, which without exception decay rapidly, and are therefore not able to furnish coal. (2) Graphite is sometimes a substitute of mica in the Gneiss; if it be phytogen, the synchronous quartz and feldspar, \&c., must also be declared so ; but that is absurd. (3) We always get amorphouz coal out of organic being, and by chemical process in the cold way, and on the contrary crystallised coal, i.e. graphite, is only to be produced by heat, and in severa ways, even out of gases. We must regard graphite as one of the arguments, proving the incandescent origin of the oldest rocks, Out of each kind of coal, also of graphite, bitumen can originate, so that bitumen is not always a sure proof of organic beings. (4) There exist many other facts proving the incandescent origin of laurentian minerals; I will add, as I believe, a new one. This origin excludes at the same time any living beings. Not one original mineral of the laurentian minerals contains water, only mica contains a very small proportion, but this chemically combined, for it cannot be expelled at red-heat. If these minerals had not had their origin in heat, they would sometimes contain water.

The other fallacious proof for the neptunic origin of laurentian rocks is their occasional stratification, and this origin would include the possibility of organic beings. No geogenetic hypotheses have been able to combine the facts of heat origin and stratification! But if we change the generally adopted opinion of Kant and Laplace, that the gases of the atmokosmos formed our globe by being condensed first into incandescent liquids, and finally into crystals, we may combine all the facts.

It is often found that we get out of hot gases mostly crystals, which partly by chemical reaction, become at first incandescent, and even quartz, feldspar, granite, and some iron minerals that we find in the granite, are known to be produced crystallised out of gases. Other facts prove that these laurentian minerals must have originated between white and red heat.

In the origin of glaciers we have an analogy for the agglomeration of the incandescent crystals into the first earth-crust without rielting, only by baking together, as being somewhat plastic, the crystals of snow harden together into ice, driving out the air between the crystals and loosing their crystallised surface, assuming also sometimes Eozöon-like forms. Glaciers not seldom show stratifications, especially in the upper part formed by temporary snow-falls. As on the top of the glacier the snow-crystals lie yet untmited, so the minerals of the laurentian period were certainly lying ununited upon the surface, and became afterwards hydrated together, when the earth-crust was cool enough, so that we find them in the post-laurentian period much more mixed and with products of neptunic erosion.

Leipzig-Eutritzsch, August 2

\section{Unobserved Impressions}

A Note to Mr. Mivart's address in the Biological Section of the British Association contains the following :-

"Having gazed vacantly through a window we revert to the pares of a manuscript we may be writing and see there the spectra of the window bars we had before unconsciously seen. Here the effect on the organisn must have been similar to what it would have been had we attended to it-i.c., it was unfelt sensation" (NATURE, vol. xx. p. 399).

The last words induce me to mention what I believe I have often observed but have hitherto presumed to be well known in psychophysics, because though they are not inconsistent with it they seem to show that it had escaped the speaker; namely, that an unobserved impression produces a much stronger effect on the organism immediately impressed than an observed impression. Of course the observation cannot be experimentally prepared; but if any one who experiences a case like that described by Mr. Mivart will allow the image to fade and then try to form another of the kind, be will be struck I believe by the inferiority of the voluntary one.

The phrase "unfelt sensation" strggests questions I wish to keep clear of ; but the phenomenon appears to me interesting, because it plainly shows that work which would be done on the retina, or on something, by an unobserved impression, is done elsewhere by an observed one.

Chesterfield, August 24

C. J. MONRO

\section{Insect-Swarms}

A WONDERFUL flight of insects has passed over here to day, consisting of the butterfly $V$. cardui and the moth $P$. gamma. They all came from the sea from the north-west and passed over the land to the south-east. I first noticed the flight at 7.30 A.M. The morning was bright and sunny with a light wind a little south of east. Great numbers of $V$. cardui were soaring at all heights, up to at least 150 feet, above and between the poplars which surround the house in which I am staying; all were going leisurely to the south-east; lower down $P$. gamma more erratie in its flight, was going in numbers in the same direction. I went down on to the grassy slope above the shore cliff. The blackberry blossoms were covered with $V$. cardui and $P$. ganma, three or four on a flower, the fussy moths much disturbing the more sedate butterflies, but each bent on holding its own. With scarcely an exception they took flight in a soutl-east direction when disturbed or when satisfied with their often, I fear, vain search for food. I stepped fifty paces from a clump of dark firs at right angles to their line of fight and counted the butterflies which passed for two intervals of two minutes; the numbers were 95 and 108, but I probably missed some of the higher ones. On the shore at 10 o'clock I counted 73 in one minute pass a space 50 paces in width; at II. 45 in one mimute 50 passed the same space. The numbers of $P$. gamma were more difficult to ascertain owing to their smaller size and more erratic flight, but as they all flew very low on the shore, not more than a foot or two at most above the water or sand, I stepped 20 paces and tried to count the moths passing within those limits with the result-one minute 32 moths, two consecutive minutes 18 moths, again two minutes $\mathrm{I} z \mathrm{O}$ at least. In the second interval a strong gust of wind checked the flight altogether, and in the third interval the moths came so fast that I missed many $I$ feel sure. The $P$. gamma were evidently much exhausted; while bathing $I$ saw several floating on the surface of the water, which took flight when touched or crawled on to a finger presented to them; some settled on me and on others while we were bathing. At I2 o'clock I passed uninterruptedly through the flight while walking from Trouville Harbour for a distance of two kilometres northwards along the shore. There was then an occasional white butterfly (Pieris) in the flight, and I also noticed two dragon-flies coming from the sea and following the same direction as the other insects; I noticed other dragon-flies with the flight inland, but they abound here. Hacl those coming from the sea accompanied the flight throughout as hawks are said to follow the flights of birds on which they prey? From the shore I climbed up the cliff, the grassy slopes above it were swarming with $P$. ganma and $V$. cardzi, nearly every flower having one visitor at least. At I.I5 P.M. P. gamma passed over in undiminished numbers, but $V$. cardui was not so abundant. At 5.30 I rode parallel with the coast line along the Honfleur road to a point rather more than ro kilometres from Trouville, passing through an uninterrupted flight of $P$. gamma all the way, but no $V$. cardui, though the butterfly still abounded on the blackberry and other blossoms by the roadside. Throughout the last two kilometres the moths were much fewer in number, but had not quite disappeared when I turned back. $P$. gamma generally flew lower than $V$. cardui, but the force which impelled them in one direction, as if their bodies were magnetised and their north pole was in the south-east, was so strong that when they met an obstruction to the course of their flight they went often over it not round it. While riding I noticed that they rose up and flew over isolated buildings, and I was curious to see whether they would do the same with a church tower. As I passed through Villerville, three came over the top of the church tower, and again at Criquebouf, three finttered up the wall, and flew over the church tower as I passed. it. At 8 P.M. I went up on to the roof of the house; the moths were then flying up the front of the house and over the roof in great numbers. The flight of $P$. gamma continued to pass the 